\title{
There is no divarication on the scientific name of jack pine?
}

Dear Sir:

1 was disappointed in the reply in April's Forestry Chronicle to F. C. Robinson's letter concerning the valid scientific name of jack pine. Surely, it is the duty of editors of influential publications like the Chronicle when expressing views on matters of current scientific controversy to present more than simply the argument of one researcher...

\section{lan Morrison}

Botanical Society of Sault Ste. Marie Sault Ste. Marie, Ontario

As a plant taxonomist, I consider it most unfortunate when a familiar scientific name for a well-known and economically or ecologically important species must be replaced on purely nomenclatural grounds. Thus I was greatly pleased to hear from my friend and fellow taxonomist, Dr. Edward G. Voss, and later to read in his paper, that the name Pinus banksiana, long in general use for the Jack Pine, was the correct name for this species after all.

James S. Pringle

Royal Botanical Gardens

Hamilton, Ontario

Thank you for your detailed explanation of the reasons for the change of name of Pinus banksiana Lamb. to Pinus divaricata (Ait.) Dumont. I have been convinced that there was a case against introducing the name of P. banksiana in 1907

Fred C. Robinson, RPF

Willowdale, Ontario
Sorry, Mr. Robinson, you have to forget it. We noted in the April issue (p. 71) that the priority of Pinus divaricata (Ait.) Dumont appeared settled to some people, but that the detectives were still at work and his conclusions could be wrong. Well, Edward G. Voss, secretary of the General Committee on Botanical Nomenclature and also of the Editorial Committee for the International Code is emphatic that Pinus banksiana Lamb. is the correct name. Here is his reason, as published in The Michigan Botanist, Volume 11, pages 26-27, 1972.

It has recently been asserted emphatically by Argus (Canad. Jour. Bot. 49: 573-576. 1971) that the nomenclaturally correct name for jack pine is Pinus divaricata (Aiton) Dumont. I cannot accept this conclusion. This binomial is based on $\mathbf{P}$. sylvestris $\delta$ divaricata Aiton (Hort. Kew. 3: 366. 1789). I agree with Argus that this name, in infraspecific rank, is validly published. The brief description ["foliis divaricatis obliquis"] and geographic statement ["Hudson's Bay Pine tree"] could refer only to jack pine. Argus and, before him, Boivin (Phytologia 15: 154. 1967) have concluded that Dumont de Courset (Bot. Cult. 3: 760. 1802) raised the epithet to specific rank the year before Lambert published the name Pinus banksiana. However, an examination of Dumont's work makes very clear that $\mathbf{P}$. divaricata was not validly published as a binomial in 1802 . Under Scots pine, Dumont recognizes several varieties (p. 760 is headed "Variétés"), the third one of which is the pin "à feuilles divergentes. P. divaricata H. K." Little (Check List of Trees, 261. 1953) referred to this as a "nom. subnud." but this is irrelevant. No description whatsoever is required for a new combination, and if this binomial were to be accepted, it is clearly based on Aiton's infraspecific epithet ["H. K." = Hortus Kewensis, as explained by Dumont in his list of abbreviations, 1: 276-278].
The important point is neither of the arguments against $\mathbf{P}$. divaricata quoted and rejected by Argus (p. 574). Art. 34 of the International Code of Botanical Nomenclature states that a name "is not validly published when it is not accepted by the author." Dumont does not accept P. divaricata as a species to which a binomial applies; he considers jack pine to be a variety of Scots pine, exactly as Aiton had done. He gives French common names as his primary nomenclatural entries, citing one or more Latin names when available (none at all for varieties 4 and 5 of $P$ in sauvage, Pin d'Ecosse, or Pin de Genève-the Scots pine). Why he cited "P. divaricata" as if it were a binomial (and similarly P. maritima) and did not cite trinomials for his varieties in this instance, as he did in many others, is not clear. Dumont (1: 31-32) does have a very definite idea of the ranks of species and variety, and he definitely treated jack pine as a variety of Scots pine.

It could be argued furthermore that "P. divaricata" as a binomial was published by Dumont in synonymy, which would also invalidate the name under Art. 34; but it is not necessary to develop this argument in addition to his unquestioned failure to accept $\mathbf{P}$. divaricata.

In view of the nomenclatural incorrectness of the name $P$. divaricata, I hope that it does not become widely accepted and used in botanical and forestry literature through failure to understand the actual circumstances under which the name was invalidly published.

Is that the end of the matter? We don't know. Battles have been fought, for example, over the names for Douglas-fir and yellow birch. We believe, however, that publication of these nomenclatural views in the Forestry Chronicle may reveal to some how a particular name may -or may not-come about. 